\title{
Scalpel or Rays? Radiotherapy and the Struggle for the Cancer Patient in Pre-Second World War Germany
}

\author{
TON VAN HELVOORT*
}

\begin{abstract}
Introduction
Cancer treatment generally comes in four modalities. ${ }^{1}$ Traditionally, surgery of tumours was the most important, while radiotherapy, chemotherapy and immunotherapy were introduced as new forms of treatment in the course of the twentieth century. Although chemotherapy and immunotherapy did not become standard until after the Second World War, X-rays and radium were used as alternatives to the surgical knife in eliminating cancer cells soon after their discovery at the end of the nineteenth century. ${ }^{2}$ This essay is concerned with the way in which radiotherapy for the treatment of cancer took shape, especially in Germany, in the first decades of the twentieth century. The analysis concentrates on two aspects.
\end{abstract}

* Ton van Helvoort, PhD, Department of History, Maastricht University, P.O. Box 616, 6200 MD Maastricht, The Netherlands; e-mail: <TvanHelvoort@compuserve.com>.

I would like to express my sincere thanks to my colleagues at the Faculty of Arts and Culture of Maastricht University, to Harmke Kamminga, Hans-Jörg Rheinberger, as well as the referees of this journal, for their constructive comments on earlier versions of this manuscript, and also to Jan Klerkx for his help in the translation work. Archival research for this study was done during a visiting fellowship at the Max-Planck-Institut für Wissenschaftsgeschichte in Berlin. Abbreviations used: GStA I. HA: Geheimes Staatsarchiv Preussischer Kulturbesitz, I. Hauptabteilung, Berlin; HUA: HumboldtUniversität zu Berlin, Archiv; Char.-Dir.: CharitéDirektion; Med. Fak.: Medizinische Fakultät.

\footnotetext{
${ }^{1}$ See, for instance, Michael Peckham, Herbert Pinedo, and Umberto Veronesi (eds), Oxford textbook of oncology, Oxford University Press, 1995. For a "landmark" history of oncology see Michael B Shimkin, Contrary to nature: being an illustrated commentary on some persons and events of historical importance in the development of knowledge concerning cancer, Bethesda, MD, US Department of Health, Education, and Welfare,
}

1977; see also David Cantor, 'Cancer', in W F Bynum, and R Porter (eds), Companion encyclopedia of the history of medicine, vol. 1 , London, Routledge, 1993, pp. 537-61. On cancer therapy see also Caroline C S Murphy, 'From Friedenheim to hospice: a century of cancer hospitals', in L Granshaw and R Porter (eds), The hospital in history, London, Routledge, 1989, pp. 221-41.

${ }^{2}$ For a history of radiology in a broad sense of the term, i.e., including radiodiagnostics, see, for instance, E R N Grigg, The trail of the invisible light: from $X$-Strahlen to radio(bio) logy, Springfield, IL, Charles C Thomas, 1965; Ruth Brecher, and Edward Brecher, The rays: a history of radiology in the United States and Canada, Huntington, NY, Robert E Krieger, 1969; Ronald L Eisenberg, Radiology: an illustrated history, St Louis, Mosby-Year Book, 1992; Richard F Mould, $A$ century of $X$-rays and radioactivity in medicine: with emphasis on photographic records of the early years, Bristol, Institute of Physics Publishing, 1993. On the history of chemotherapy and immunotherapy see two recently published studies: Ilana Löwy, Between bench and bedside: science, healing, and interleukin-2 in a cancer ward, Cambridge, MA, Harvard University Press, 1996, and Stephen S Hall, $A$ commotion in the blood: life, death, and the immune system, New York, Henry Holt, 1997. 


\section{Ton van Helvoort}

The first is that of the struggle between the representatives of orthodox medicine, those using the scalpel in the fight against cancer, that is to say, general surgeons, internists, gynaecologists, dermatologists and oto-laryngologists, and those who perceived in rays a new, separate form of treatment of the cancer patient, i.e. the radiotherapists-to-be. When $\mathrm{X}$-rays and radium were found to be effective in the combat against cancer, radiotherapists sought to create their own niche within the existing ecology of medical professions. In his System of professions, Andrew Abbott argues that the establishment of a profession is best analysed in terms of tasks, jurisdiction and competition. ${ }^{3}$ The present essay illustrates that this "infighting" over radiotherapy took the form of a struggle for the cancer patient and for jurisdiction over the use of the new techniques such as $\mathrm{X}$-rays and radium.

The second focus of this essay is the role of costly instruments and resources and their impact on the organization of therapy. X-rays as well as radium could be deployed as small-scale or large-scale techniques. Their first therapeutic applications were small-scale, viz, X-ray tubes which had already been used for diagnostics were now applied therapeutically by merely extending the duration of the application; radium was used in milligram quantities for superficial tumours. In the 1920s, however, a breakthrough took place. The X-ray instruments were now operated at several hundreds of kilovolts, and so-called radium bombs or canons, containing several grams of radium, were designed for cancer therapy. In addition, more knowledge was available on the risks accompanying these techniques, for example those of skin burns or tumours. These specific conditions stimulated the establishment of large centralized institutes for cancer treatment and cancer research. At the 1926 congress on 'Cancer Control', held at Lake Mohonk, New York, Claude Regaud, director of the "Therapeutic Service" of the Paris-based Curie Foundation claimed that the developments outlined above indicated the necessity of:

... calling in for the examination and treatment of patients, men of various specialties whose work must be exactly co-ordinated; of placing at the service of diagnosis and treatment different kinds of laboratories, all well equipped; of bringing together special X-ray apparatus which is numerous, heavy, and costly to purchase and maintain; of employing large quantities of radium - all this explains adequately the recent organization of anti-cancer therapy with a view to a work that is to be accomplished by a collective staff, in special, well-endowed establishments. ${ }^{4}$

In France, England, Sweden and the United States such centralized cancer institutes were indeed established in the first decades of the twentieth century, mainly supported by huge philanthropic donations. Although even in these specialized establishments a certain degree of rivalry would have existed between radiotherapists and medical specialists such as surgeons, internists and gynaecologists, these institutes were instrumental in establishing radiotherapy as an independent profession and in the

\footnotetext{
${ }^{3}$ Andrew Abbott, The system of professions: an essay on the division of expert labor, University of Chicago Press, 1988.

${ }^{4}$ Claude Regaud, 'What is the value and what should be the organization and equipment of institutions for the treatment of cancer by radium
}

and X-Rays?', in American Society for the Control of Cancer, Cancer control, Chicago, Surgical Publishing Co., 1927, pp. 116-40, p. 120. 


\section{Radiotherapy in Pre-Second World War Germany}

development of a multi-disciplinary approach to cancer treatment. In Germany, however, radiotherapy lacked a centralized organization until well after the Second World War, and fell under the jurisdiction of various specialities such as surgery and gynaecology.

This delay in the centralization of German radiotherapy has been generally acknowledged. $^{5}$ In 1959, the Swiss radiologist Hans $R$ Schinz stated that in the organization of radiotherapy “Germany, Röntgen's homeland, has curiously dropped behind". ${ }^{6}$ And in a discussion of the development of German medical disciplines, Hans-Heinz Eulner concluded in regard to radiotherapy that the Anglo-Saxon and Scandinavian countries and Switzerland were quite advanced in the centralization of radiotherapy while in Germany "the clinicians had opted for the principle of decentralization". ${ }^{7}$ Thus, German radiotherapy and specialized cancer institutes became institutionalized relatively late in comparison to countries such as France, England, Sweden and the United States. ${ }^{8}$

The conflicts over the introduction of radiotherapy in Germany are well documented by archival and published sources, because during the 1930s a struggle developed over the Institut für Krebsforschung (Institute for Cancer Research; hereafter IfK) of the Berlin Charite hospital. At that time, the IfK was led by the Jew Ferdinand Blumenthal (1870-1941), who had also been deputy head when the Institute was established in 1903 by Ernst von Leyden. Von Leyden, who had been a professor of internal medicine in Straßburg before he was appointed head of the First Medical Clinic of the Charité in 1885, was Germany's leading internist and became the first director of the IfK. After a period in which the Institute was led by others, Blumenthal had become director in the mid-1910s, and in the late 1920s he worked towards the centralization and regulation of German cancer control in general and of radiotherapy in particular. In this he was supported by the Reichsausschuß für Krebsbekämpfung (State Committee for Cancer Control), which was inaugurated in 1931, signalling the first definite involvement of the German state in this aspect of public health. Blumenthal's desire for centralization, backed up by the Reichsausschuß, met with powerful resistance from other Charité clinics, the medical faculty of Berlin University and the German societies for surgery and gynaecology. In the early 1930s, the latter specialists successfully penetrated the Reichsausschuß, and National Socialist measures against Jews helped to ensure the neutralization of attempts to centralize radiotherapy in Germany and to establish one or two national cancer institutes.

Thus, the actual development of radiotherapy in Germany differed from that in

\footnotetext{
${ }^{5}$ On German radiotherapy, see Hans-Peter Heilmann, 'Radiation oncology: historical development in Germany', Int. J. Radiat. Oncol., Biol., Phys., 1996, 35: 207-17, pp. 207-9. See also Heinz Goerke, Fünfundsiebzig Jahre Deutsche Röntgengesellschaft, Stuttgart, Georg Thieme, 1980 , pp. 96-103.

${ }^{6}$ Hans R Schinz, Sechzig Jahre medizinische Radiologie: Probleme und Empirie, Stuttgart, Thieme, 1959, p. 223.
}

\footnotetext{
${ }^{7}$ Hans-Heinz Eulner, 'Röntgenologie', in idem, Die Entwicklung der medizinischen Spezialfächer an den Universitäten des deutschen Sprachgebietes, Stuttgart, Ferdinand Enke, 1970, pp. 421-6, p. 425.

${ }^{8}$ Gustav Wagner and Andrea Mauerberger, Krebsforschung in Deutschland: Vorgeschichte und Geschichte des Deutschen Krebsforschungszentrums, Berlin, Springer, 1989.
} 


\section{Ton van Helvoort}

countries such as France, England, Sweden and the USA. It will be argued below that this was related to the strength of German orthodox specialists, the costly nature of radium and the lack of German resources for radioactive substances, as well as to the absence of a philanthropic tradition with regard to cancer control and research and the reluctance of the German state to support the latter. ${ }^{9}$ It must be admitted that the tension between surgeons and medical specialists on the one hand and radiotherapists on the other about the jurisdiction over the new cancer treatment modalities occurred in all countries, but the specifics of the German situation made the disaccord more visible and the consequences more enduring.

\section{Introducing Radiotherapy into Cancer Treatment}

In the late nineteenth century, surgery was the standard treatment of cancer and had achieved a high level of perfection. The possibility of general anaesthesia had lessened the fear of operations and also allowed them to last longer. Furthermore, under the influence of the work of Joseph Lister, Louis Pasteur and Robert Koch, the use of antiseptics and a strictly aseptic protocol had ameliorated mortality and morbidity. ${ }^{10}$ Surgical intervention in cancer was based on the consideration that early cancer was a local disease and only in a later phase did the tumour cells spread via the lymph nodes, after which the disease could establish itself in other organs (metastasis). ${ }^{11}$

In the first decades of the twentieth century, cancer patients constituted a quarter of the surgeon's patients. ${ }^{12}$ For gynaecologists too, the treatment of cancer patients made up a substantial part of their daily activities. Exterior forms of gynaecological cancer, e.g. breast cancer, were relatively simple to deal with surgically. In many cases of cervical cancer, however, the tumour was difficult to access through the vagina. This mode of operation resulted in a high percentage of relapses, i.e. patients in whom the tumour returned or metastasis was not prevented. Difficult cases of cervical cancer were often approached via the abdominal wall (laparotomy), a major operation in which the chance of recovery was heavily influenced by the woman's constitution. ${ }^{13}$ In addition to these difficulties, there were many inoperable cases of cancer patients whose tumours were too large to be removed surgically or had fused with surrounding organs and tissues. Clearly there was need for an alternative to the scalpel.

In late 1895, Wilhelm C Röntgen reported that, while working with a cathode tube, he had observed a new kind of rays. ${ }^{14}$ These he denoted as "X-rays", to indicate that

\footnotetext{
${ }^{9}$ On philanthropy, see Lily E Kay,

'Rethinking institutions: philanthropy as an historiographic problem of knowledge and power', Minerva, 1997, 35: 283-93.

${ }^{10}$ For the role of surgery in cancer, see, for instance, George J Hill, II, 'Historic milestones in cancer surgery', Semin. Oncol., 1979, 6: 409-27.

${ }^{11} \mathrm{Cf}$. Charles P Childe, The control of a scourge, or, how cancer is curable, New York, E P Dutton, 1907.
}

\author{
${ }^{12}$ Wolfgang Genschorek, Ferdinand \\ Sauerbruch: ein Leben für die Chirurgie, Leipzig, S \\ Hirzel, 1981, p. 181. \\ ${ }^{13}$ Walter Stoeckel, Erinnerungen eines \\ Frauenarztes, Leipzig, S Hirzel, 1979, pp. 109-10. \\ ${ }^{14}$ Gerald L'E Turner, 'Röntgen, Wilhelm \\ Conrad', in C C Gillispie (ed.), Dictionary of \\ scientific biography, vol. 11, New York, Charles \\ Scribner's Sons, 1981, pp. 529-31.
}




\section{Radiotherapy in Pre-Second World War Germany}

their nature was still unknown. Röntgen observed that these rays could pass through the fleshy part of a hand but were attenuated by bones. The visualization of the inside of the body would prove to have an enormous impact on medicine, and even on the image man had of himself. ${ }^{15}$ Within diagnostics, X-rays were used in three ways, namely in trauma medicine, bone diseases and fractures, and the search for corpora alienum such as bullets (Fremdkörpersuche). Therefore, X-ray diagnostics were applied mostly within surgery, orthopaedics and internal medicine. Each specialism claimed the application of the X-ray technique to its own field of competence. ${ }^{16}$

In the early years of the twentieth century, the Surgical Clinic as well as the First and Second Medical Clinics of the Charité obtained their own X-ray departments. In 1901, the Second Medical Clinic, headed by Friedrich Kraus, got such facilities, and three years later the First Medical Clinic, headed by Ernst von Leyden, obtained them too. Furthermore, the Nerve Clinic, the Dermatological Clinic and the Medical Out-Patient Clinic had their own X-ray equipment installed. ${ }^{17}$

Soon after the discovery of X-rays and their amazing ability to pass through flesh, a second application was found for them. It was claimed that X-rays had a specific destructive effect on rapidly dividing tissue cells, especially tumours, compared with their effect on normal tissue. ${ }^{18}$ Because of the problems discussed above in relation to the surgical treatment of cervical cancer, X-rays were used by the gynaecologist Bernhard Krönig from Freiburg im Breisgau to treat this disease, with highly promising results. In 1913 Krönig presented his results at the German Congress of Gynaecologists in Halle. This congress was a landmark in the application of radiotherapy to gynaecological cancer. ${ }^{19}$ According to the Charité's gynaecologist Walter Stoeckel, it was a historic occasion because of the jubilant atmosphere which spread "right up to the most senior Geheimräte." Prominent gynaecologists such as Albert Döderlein, Ernst Bumm and Carl Menge argued that if the results reported at Freiburg were corroborated, they would refuse to use the scalpel any longer. ${ }^{20}$

For those gynaecologists who tried out radiotherapy, there was no doubt that the new cancer intervention technique had a valid role to play. Carl J Gauß from Freiburg, one of Krönig's co-workers, and the radiotherapists Hans Meyer from Kiel and Richard Werner from Heidelberg felt that the time was right for an independent periodical and in 1912 they established the journal Strahlentherapie

\footnotetext{
${ }^{15}$ Bettyann Holtzmann Kevles, Naked to the bone: medical imaging in the twentieth century, New Brunswick, NJ, Rutgers University Press, 1997. This book discusses the impact of X-rays on man's self-image and society in general.

${ }^{16}$ This situation was recently expressed evocatively as follows: "at the time of their discovery, radiographs were limited to small glass plates that reflected the organizational deconstruction of medicine into specialties-each concentrating on the anatomical area covered by one small plate." Ibid., p. 299.

${ }^{17}$ Kurt-Achim Hinze, 'Aspekte der Entwicklung der Röntgenologie an der Charité zu Berlin in den ersten drei Jahrzehnten nach der Entdeckung der Röntgenstrahlen', PhD thesis,
}

Humboldt-Universität Berlin, 1978, pp. 20-33. In the early 1930 s, an attempt was made to unite the various X-ray departments into one independent unit, but this endeavour failed.

${ }^{18}$ The idea that X-rays were selectively more destructive to tumour cells than to normal cells was not universally accepted, however; see David von Hansemann, 'Krebsheilmittel in Theorie und Praxis', Zeitschrift für Krebsforschung, 1914, 14: 139-50, pp. 143-4.

${ }^{19}$ Hans Meyer, 'Aus der Pionierzeit der Strahlenheilkunde: ein Lorbeerblatt auf das Grab von Bernhard Krönig, Freiburg i. Br.', Med. Klin., 1955, 50: 65-6, p. 66.

${ }^{20}$ Stoeckel, op. cit., note 13 above, p. 86. 


\section{Ton van Helvoort}

(Radiotherapy). ${ }^{21}$ Werner was the radiotherapist at the Heidelberg Samariterhaus, established by the surgeon Vincenz Czerny at the beginning of the twentieth century. ${ }^{22}$ Although Czerny was a surgeon, he clearly saw radiotherapy as having an important role to play in cancer treatment. In a short introductory note to the new journal, he wrote that under favourable conditions radiotherapy "can even replace the surgeon's knife. Surgeons, who are constantly overburdened by the many different demands made on their skills, will welcome being relieved of many thankless tasks. In fact, surgeons have recently learned to adapt to the needs of radiologists, and will prepare patients for them by treating open wounds and by dissecting out or exposing tumours, etc." 23 Apparently, Czerny was willing to make surgery secondary to radiotherapy in the treatment of cancer, an attitude that was not shared by many surgeons. Although many cancer patients were in a poor condition already, surgeons often did not hesitate to burden them with an exhausting operation. Much was at stake in the competition between surgery and radiotherapy: the status and authority of surgery with regard to cancer treatment, as well as certain financial interests.

As indicated above, most medical specialists were familiar with the technique of $\mathrm{X}$-ray diagnostics. The move from X-ray diagnostics to X-ray therapy seemed to be only a quantitative change. In the early years, for instance, $X$-ray therapy of cervical cancer was performed by the simultaneous application of two X-ray tubes placed on the abdomen and directed at the cervix, and a third one irradiating the cervix through the vagina. ${ }^{24}$

Two inventions, made during the First World War, would make X-ray therapy much more efficient. The first was the "hot-cathode tube" (Glühkathodenröhre), which was developed by William D Coolidge from Schenectady, New York, and the second was the "cascade transformer". This powerful apparatus necessitated a more efficient dosimetry in order to prevent serious injuries to the patient. ${ }^{25}$ Experts tried to solve the problems of quantification by giving a precise description of the instruments used, i.e., the construction of the tube, the electrical power and current applied, and the time period of exposure. Radiation was also empirically quantified in terms of the dose the skin could withstand, later followed by more precise methods of dosimetry such as colorimetry and the measurement of ionization caused by the radiation over a specified

${ }^{21}$ Carl J Gauß, Hans Meyer, and Richard Werner, 'Zur Einführung', Strahlentherapie, 1912, 1: $1-3$.

${ }^{22}$ For a brief history of the cancer institute/ hospital Samariterhaus at Heidelberg, see Friedrich Voelcker, 'Zur Eröffnung des Institutes fur experimentelle Krebsforschung in Heidelberg', Münch. Med. Wochenschr., 1906, 53: 1919-21; and Vinzenz Czerny (ed.), Das Heidelberger Institut für experimentelle Krebsforschung. I. Teil. Geschichte, Baubeschreibung, wirtschaftliche Verhältnisse, Leistungen des Instituts, Aktensammlung, Tübingen, $\mathrm{H}$ Laupp'schen Buchhandlung, 1912.

${ }^{23}$ Vincenz Czerny, 'Die Bedeutung der Strahlenbehandlung für die Chirurgie', Strahlentherapie, 1912, 1: 4-5, p. 5.

\footnotetext{
${ }^{24}$ Kurt Warnekros, 'Zur Röntgentechnik der Carcinombestrahlung', Verh. Berlin. med. Ges. Gesellschaftsjahre 1913, 1914, 44: 416-23, p. 423. For a discussion of the widespread early use of radiotherapy in North America, see Charles $\mathbf{R}$ R Hayter, 'The clinic as laboratory: the case of radiation therapy, 1896-1920', Bull. Hist. Med., 1998, 72: 663-88.

${ }^{25}$ Unfamiliarity with the effects of radioactive rays also claimed many victims amongst radiotherapists themselves. Those who died as a consequence of immediate or protracted radiation were included in an Ehrenbuch (Book of honour); see Hermann Holthusen, Hans Meyer, and Werner Molineus (eds), Ehrenbuch der Röntgenologen und Radiologen aller Nationen, Munich, Urban \& Schwarzenberg, 1959.
} 


\section{Radiotherapy in Pre-Second World War Germany}

period. ${ }^{26}$ In addition to X-ray therapy, however, there was a second type of radiation used in the treatment of tumours, namely "radium therapy".

\section{Radium Therapy in Germany}

In the context of the discovery of X-rays and their presumed relation to phosphorescence, Antoine-Henri Becquerel made a study of uranium salts. During one of these experiments, in early 1896 , he discovered a new form of radiation. ${ }^{27}$ This discovery was elaborated upon by Marie (Sklodowska-)Curie who used a piezo-electrometer developed by her husband Pierre Curie to study whether this kind of radiation also emanated from other elements. She found that thorium compounds gave evidence of the same property, and this new form of energy from uranium and thorium she named radioactivity. Subsequently she found that pitchblende (uraninite; Uranpecherz) produced more radioactivity than could be explained on the basis of its uranium content. Apparently, a further radioactive substance had to be present, and her research resulted in the isolation of the element polonium, the discovery of which was announced in July 1898. Subsequently, a second element was isolated, which was named radium (announced in December 1898) and possessed 2 million times more radioactivity than uranium. The fact that one part of radium had to be isolated from 4 million parts of pitchblende meant that enormous investments had to be made to isolate enough. At that time, the only uranium mine was to be found in Joachimstal, Bohemia, which was then under the authority of Austria (it is now part of the Czech Republic). ${ }^{28}$

The therapeutic effect of X-rays on dermatological disorders (for instance, lupus) stimulated the application of radium to this kind of disease as well. ${ }^{29}$ The application of radium to dermatology and benign tumours promptly resulted in striking improvements. Radium therapy was even used to heal skin lesions that had resulted from X-ray burns. Success was reported with malignant tumours too. Deeply situated tumours could be caused to regress by placing tubes containing radium inside the tumour (interstitial radium implantation). ${ }^{30}$

Since the supplies of uranium were limited, as a consequence of radium's therapeutic application, the price skyrocketed. In 1911, radium was found in carnotite (vanadium oxide) in Colorado (USA), which meant that an important additional source had become available. In Germany, however, the shortage of radium was dire.

In 1904, the German Emperor commissioned Paul Ehrlich to devote himself to cancer research. A few years later, Ehrlich was asked by the Minister of Science von Trott zu

\footnotetext{
${ }^{26}$ Goerke, op. cit., note 5 above, pp. 103-5; Eisenberg, op. cit., note 2 above, pp. 492-7. See also Arne Hessenbruch, 'The commodification of radiation: $\mathrm{X}$-ray and radium standards, 1896-1928', PhD thesis, Cambridge University, 1995.

${ }^{27}$ See, for instance, Alfred Romer, 'Becquerel, (Antoine-)Henri', in Gillispie (ed.), op. cit., note 14 above, vol. 1, pp. 558-61.

${ }^{28} \mathrm{On}$ the discovery of radium, see Adrienne $\mathbf{R}$ Weill, 'Curie, Marie (Maria Sklodowska)', in Gillispie (ed.), op. cit., note 14 above, vol. 3, pp.
}

497-503; Jean Wyart, 'Curie, Pierre', in Gillispie (ed.), op. cit., note 14 above, vol. 3, pp. 503-8; see also Eisenberg, op. cit., note 2 above, pp. 43-50.

${ }^{29}$ Eisenberg, op. cit., note 2 above, pp. 481-510.

${ }^{30}$ Ibid., pp. 511-26. See also Bernard Pierquin, ' $L a$ radiumthérapie de sa naissance à sa mort, 1896-1976', Cancer Radiothérapie, 1997, 1: 5-13. For the development of radium dosimetry, see Eisenberg, op. cit., note 2 above, pp. 523-5, and Hessenbruch, op. cit., note 26 above. 


\section{Ton van Helvoort}

Solz to report on the availability of radium in Germany for the treatment of cancer. ${ }^{31}$ Ehrlich argued that one metric ton of Uranpecherz of the best quality yielded only 0.2 grams of radium. The ore from Joachimstal had this quality and the French also had a radium production facility at Nogent-sur-Marne. The only German producer was Buchler \& Co. at Braunschweig, and the only German uranium ore was mined at Kreuznach, Bad Dürkheim and Baden-Baden, but it was of a much lower grade. German scientists did manage to find an alternative for radium, however. From the residues of the production of thorium for gas mantles, the radioactive substance mesothorium could be extracted, which was also useful for radiotherapy. ${ }^{32}$

In a 1909 letter to the German Emperor, von Trott zu Solz presented an outline of the distressing situation regarding the availability of radium for cancer treatment in Germany. ${ }^{33}$ In this report the world supply of radium (in the form of radium bromide) was assessed at 9 grams, of which one-third was under Austrian authority. Two grams were held in the Institute of Physics at Vienna, while three-quarters of a gram were on loan to England. In Paris, Marie Curie had one to one and a half grams, while the rest was distributed over numerous institutes all over the world. The worrisome situation for Germany is clear from the following summary: in Berlin the Akademie der Wissenschaften (Academy of Sciences) held $27 \mathrm{mg}$ semi-pure and $8 \mathrm{mg}$ pure radium bromide, while even less was available at the Charite and at the Technical University. Von Trott zu Solz argued that one quarter of a gram was urgently needed to keep up with ongoing research. As the price of $1 \mathrm{mg}$ radium bromide had risen from 12 Marks to 150 Marks over the previous decade, the Emperor was asked to make available 37,500 Marks for the purchase of that quarter of a gram, which was to be supplied by the Chininfabrik Buchler \& Co. at Braunschweig.

In response to the excitement caused by Krönig's presentation at the Congress of Gynaecologists, August von Wassermann, who had devised the serological test for syphilis which was named after him, was asked in the same year to evaluate cancer treatment by radium and mesothorium. ${ }^{34}$ Wassermann stated that the results obtained by treating tumours with rays emitted by radium or mesothorium were most promising and that clinicians were already becoming bold enough to speak of "curing" cancer. However, the action of these rays had to be a direct one, meaning that radioactive rays were ineffective where the tumour had already metastasized and the tumour cells had spread through the body. Wassermann reported that the gynaecologist Krönig made use of 400 to $500 \mathrm{mg}$ of radioactive substance. He also stated that the production of mesothorium, the alternative for radium, was difficult

\footnotetext{
${ }^{31}$ Letter from Paul Ehrlich; GStA I. HA Rep 89 nr. 24528 , p. 57 e.v. (no date).

${ }^{32} \mathrm{On}$ the influence of chemists on the German Empire, see Jeffrey A Johnson, The Kaiser's chemists: science and modernization in Imperial Germany, Chapel Hill, University of North Carolina Press, 1990.
}

\footnotetext{
${ }^{33}$ Letter from von Trott zu Solz, 11 Sept. 1909; GStA I. HA Rep 89 nr. 24528, 54-56a.

${ }^{34}$ Letter from August von Wassermann, 16 June 1913; GStA I. HA Rep 89 nr. 24528, $104-9$.
} 


\section{Radiotherapy in Pre-Second World War Germany}

and costly. The German Glühlicht Gesellschaft (Gas Mantle Company) had an annual production of $2 \mathrm{~g}$, and in 1913 each mg cost 200 to 300 Marks. $^{35}$

Because of the price and scarcity of mesothorium, it was suggested in the press that its production should perhaps be brought under public ownership. Von Trott zu Solz advised the Emperor regarding the medical use of radioactive substances. ${ }^{36}$ He stated that medical treatment required at least a sample of $200 \mathrm{mg}$ of radium or mesothorium (which could of course be used repeatedly) and that "the areas of gynaecological disorders, surgery, skin and venereal diseases, internal medicine and ear, nose and throat diseases" were proper fields of use. In cases where radiotherapy did not cure, it was at least effective in killing pain, which was a valuable application of these substances in itself. Therefore, the Minister of Science had acquired 1250 $\mathrm{mg}$ of radium and $250 \mathrm{mg}$ of mesothorium for a total sum of 500,000 Marks. As regards the nationalization of mesothorium production, von Trott zu Solz had himself been advised by Germany's most renowned chemists and physicists, Otto Hahn, Emil Fischer and Walther Nernst. The latter arrived at the following conclusions.

Mesothorium was produced from monazite, which was mined only in Brazil. From 1 metric ton of monazite, 2 to $2.5 \mathrm{mg}$ mesothorium was produced. If mesothorium was to be produced by the state, it would cost 320 to 400 Marks per mg, which was about twice the price current at that moment. Furthermore, numerous production installations would have to be bought, as well as compensation paid for the various patents to the companies affected. ${ }^{37}$ Worldwide, about 7 grams of mesothorium were produced each year, of which about 5 grams were extracted in Germany. Furthermore, there was the real possibility that Brazil would work up mesothorium by itself, just as Austria had done with the production of radium. In a report to the Ministerialdirektor (secretary general), Naumann, Walther Nernst therefore urged that the usefulness of mesothorium should not be made public: "Let us hope the German press will not make too much of the importance of mesothorium, as this might lead to increases in the price that German industry has to pay for the raw material, i.e., monazite." 38

But there were other arguments for not bringing the production of mesothorium under public ownership. First, there was the real possibility that radioactive substances would shortly be produced artificially. Furthermore, in a report to von Trott zu Solz, the organic chemist Emil Fischer argued that in the near future tumours could perhaps be destroyed by making use of X-rays or chemotherapy, which implied that radium and mesothorium would no longer be indispensible. Fischer, a 1902 Nobel laureate, concluded in 1913: "I am therefore of the opinion that X-rays should be utilized, and that small, suitable machines should be constructed for this purpose." ${ }^{39}$

\footnotetext{
${ }^{35}$ Although clinics could actually purchase mesothorium, individual doctors were only allowed to hire it, in order to prevent monopolization and speculation. See Verhandlungen der Deutschen Gesellschaft für Gynäkologie-Fünfzehnte Versammlung Abgehalten zu Halle a. S. am 14.-17. Mai 1913, Leipzig, Johann Ambrosius Barth, 1914, p. 394.
}

\footnotetext{
${ }^{36}$ Letter from von Trott zu Solz, 22 Sept. 1913; GStA I. HA Rep 89 nr. 24528, 110-15.

${ }^{37}$ Ibid.

${ }^{38}$ Letter from Walther Nernst, 31 Aug. 1913; GStA I. HA Rep 89 nr. 24528, 124-7, p. 127.

${ }^{39}$ Letter from Emil Fischer, 6 Sept. 1913; GStA I. HA Rep 89 nr. 24528, 121-3, p. 123.
} 


\section{A Ray of Hope: \\ The Institut für Krebsforschung, 1903-1928}

The successes of medical science, and bacteriology in particular, during the last decades of the nineteenth century stimulated a renewed attack on cancer. Despite the progress of pathology, the cause of cancer still was a mystery. In 1900 the decision was taken in Germany to organize a census or Sammelforschung regarding cancer, in order to investigate whether proof could be obtained of the infectious nature of the disease. Chaired by Ernst von Leyden, head of the First Medical Clinic of the Charité, the Komitee für Krebsforschung (Cancer Research Committee) was founded. At its inauguration, von Leyden declared himself a proponent of the parasitical hypothesis in the question of cancer etiology: "The theory which is now gaining prominence, and to which I myself fully subscribe, is that of the parasitical nature of cancerous diseases. It is the only theory which is in sufficient agreement with the observations and with current biological views." 40

In order to confirm or refute this hypothesis, von Leyden established the Institut für Krebsforschung (Institute for Cancer Research) in 1903, with Ferdinand Blumenthal as physician in charge. The Institute was small, consisting of two wards for ten patients each (one for men, one for women) and one laboratory. ${ }^{41}$

In 1911, von Wassermann reported on a presumed medical breakthrough in that he had found that transplantation tumours (i.e. tumours cultured by transplantation and thus not developed spontaneously) in mice could be made to regress when the mouse was treated with a selenium compound. Although this was only an animal cancer model, it was received as a possible breakthrough for human cancer. ${ }^{42}$ Because of this apparent progress in cancer chemotherapy, and after the sudden death of von Leyden in 1910 in a car accident, the Institute was placed under the directorship of the chemist Emil Fischer, with Georg Klemperer as chief physician. Fischer and Klemperer pursued the application of chemotherapy, especially of selenium compounds, in cancer patients, but in 1914 they had to conclude that this type of compound had no beneficial effect on human cancer. Subsequently, Johannes Orth-Rudolf Virchow's successor as head of the famous Pathological Institute of the Charite-was placed in charge of the Institut für Krebsforschung, although the de facto day-to-day management was in the hands of Ferdinand Blumenthal.

Blumenthal initiated a variety of experimental research projects, many of them experimental models which were unconventional for the clinician: transplantation tumours, chemical carcinogenesis by Teerpinseln (tar painting) of mice and rats,

\footnotetext{
${ }^{40}$ Ernst von Leyden, Kirchner, et al., Verhandlungen des Comités für Krebsforschung Heft I. 1900-1902, Sonderabdruck aus der 'Deutschen Medizinischen Wochenschrift', Jahrgang 1900-1902, Berlin, G Bernstein, 1902, pp. 3-4.

${ }^{41}$ Ernst von Leyden, and Ferdinand Blumenthal, 'Die Abteilung für Krebsforschung an der I. medizinischen Universitätsklinik', Charité-Annalen, 1904, 28: 36-44. Ferdinand Blumenthal defended his MD thesis in 1895 and
}

completed his Habilitation in 1899. Besides working at the IfK, Blumenthal was head of internal medicine at the Israeli Hospital from 1902 to 1923.

${ }^{42}$ See August von Wassermann, Franz Keysser, and Michael Wassermann, 'Beiträge zum Problem: Geschwülste von der Blutbahn aus therapeutisch zu beeinflussen', Dtsch. med. Wochenschr, 1911, 37: 2389-91, and anon., 'Kleine Mitteilungen', ibid., 1911, 37: 2391-2. 


\section{Radiotherapy in Pre-Second World War Germany}

Rous sarcoma in chickens, and crown galls of plants. To many clinicians, the relevance of such experimental models for the problem of human cancer was by no means evident. One argument for this scepticism was the difference between the results of chemotherapy in animals and humans. ${ }^{43}$ Orth had also succeeded von Leyden as chairman of the Deutsche Zentralkomitee für Krebsforschung (the former Komitee für Krebsforschung) and after the withdrawal of the first secretary of the committee in 1919, Blumenthal took over this function. ${ }^{44}$

Even under Georg Klemperer, the IfK had been in need of an outpatient clinic in order to contact patients as soon as possible, and to intervene in the disease process in its earliest stages. This would allow the latest diagnostic methods and therapies to be tried and evaluated. In 1911, Klemperer therefore asked Naumann for permission to open an outpatient clinic, arguing that there was a special need for patients who had not yet been clearly diagnosed with cancer. Sometimes it took several weeks before the decision was made to operate, and meanwhile the ambulant patient could be diagnosed in more detail. Subsequently, surgery could be performed at the surgical clinic. Klemperer emphasized that until then the IfK had mostly received patients who were in a desperate condition. The reason was that the intake of patients was indirect, through referral from the other Charite institutes. This resulted in a situation "in which our patients come from clinics which allow them to come here only after they have lost any practical medical or scientific interest in them and when only the human aspect of euthanasia can be considered". ${ }^{45}$ Ernst Pütter, the Verwaltungsdirektor (administrative director) of the Charité, underlined the IfK's need for patients in the "various stages of the disease" and therefore of a Poliklinik für Krebskranke und Krebsverdächtige (Outpatient Clinic for Cancer Patients and Cancer Suspects). ${ }^{46}$ The IfK's wish was to be granted in 1915.

Klemperer's letter, quoted above, reveals a tension between the Institut für Krebsforschung and the other specialist fields which were involved in cancer patient care, such as surgery, internal medicine and gynaecology. Klemperer hastened to state that the IfK would never admit patients to its beds who were operable; these were to be referred for surgery immediately. But there were also many tumours which were inoperable, such as those in the pleura, the lungs, the liver, spleen, thymus, stomach and, to some extent, in the intestine, as well as patients who had already been operated upon but who had suffered relapses (often cases of cancer of the breast or cervix). Klemperer was aware that an outpatient clinic would provoke opposition from the other Charite clinics, but gave the assurance that: "There would be no competition with the surgeons

\footnotetext{
${ }^{43}$ This argument is elaborated in Ton van Helvoort, 'A dispute over scientific credibility: the struggle for an independent Institute for Cancer Research in pre-World War II Berlin', Stud. Hist. Philos. Biol. Biomed. Sci., 2000, 31: 315-54.

${ }^{44}$ Matthias Kaiser, 'Zur Geschichte des Deutschen Zentralkomitees zur Erforschung und
}

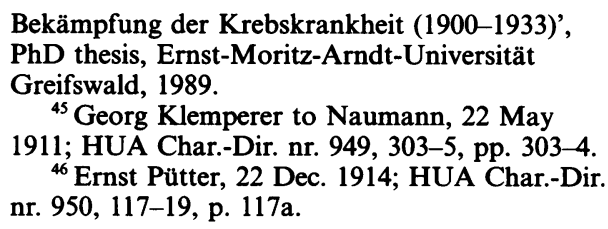




\section{Ton van Helvoort}

whatsoever. Our department would select internal, inoperable cases or inoperable relapses of external cancers." ${ }^{\text {47 }}$ (Emphasis as in the original.)

After Blumenthal had been put in charge of the IfK, the relationship with the surgeons was one of careful manoeuvring. In a letter to the Minister für Geistliche und Unterrichts-Angelegenheiten (Minister for Educational and Spiritual Affairs) Blumenthal wrote that a useful cooperation had been established between his Institute and the Surgical Clinic. Those patients who were operable were referred, while the surgical department "sends us the tumours removed at operation, and we use them to prepare a vaccine with which we immunize the patients in order to induce their bodies to form antibodies against tumour relapses". ${ }^{48}$ Although Blumenthal stated that the relationship with surgery was more or less harmonious, Naumann informed Blumenthal that the Charite was mounting fierce resistance against the Institute. Briefly, the argument was: "The scientific research was done in other institutes, while the cancer patients could be treated at the appropriate clinics." However, Blumenthal also experienced firm support from, for example, Johannes Orth of the Pathological Institute, who had been Blumenthal's supervisor when he started his career, as well as from Ernst Pütter and from Naumann himself. ${ }^{49}$

For its research into the etiology and treatment of cancer, the IfK thus needed patients in the early stages of the disease. On the other hand, even the desperate cases of inoperable cancer patients had to be offered some hope, otherwise they would seek help from quacks, homoeopaths, and so-called "biochemists". ${ }^{50}$ Blumenthal held the opinion that one had to fight cancer by, in current terminology, a multi-modality regime in which surgery, chemotherapy, radiotherapy and immunotherapy each made its own contribution. For Blumenthal, cancer treatment had to be comprehensive, with local control of tumours being implemented by surgery and radiation. This was supplemented by the systemic and constitutional treatment of the disease, in which chemotherapy and immunotherapy were additional treatment modalities, to aid the patient's convalescence. Except for smaller surgical manipulations, no substantial surgery took place at the IfK. ${ }^{51}$ Under Blumenthal's directorship, radiotherapy became the foundation of the Institute on the basis of which even the most desperately ill cancer patient could be offered a ray of hope for recovery and at least some form

\footnotetext{
${ }^{47}$ Klemperer to Naumann, 22 May 1911; HUA Char.-Dir. nr. 949, 303-5, p. 303a, p. 304, respectively.

${ }^{48}$ Blumenthal to the Minister für Geistliche und Unterrichts-Angelegenheiten, 23 June 1915; HUA Char.-Dir. nr. 950, 150-8, p. 155.

Immunotherapy, however, has now regained great interest, after having been out of favour for quite some time. See, for instance, Hall, op. cit., note 2 above. See also Martin Gore and Pamela Riches, 'The history of immunotherapy', in M Gore and $P$ Riches (eds), Immunotherapy in cancer, Chichester, John Wiley, 1996, pp. 1-9.

${ }^{49}$ Ferdinand Blumenthal, Rhoda Erdmann, Ludwig Halberstädter, and Hans Hirschfeld, Zum 25jährigen Bestehen des Universitätsinstituts für Krebsforschung an der Charité, am 8. Juni 1928,
}

Berlin, Julius Springer, 1928, pp. 12, 5, respectively.

${ }^{50}$ Ibid., pp. 7-9.

${ }^{51}$ Ferdinand Blumenthal, '25 Jahre

Krebsbehandlung', Med. Klinik, 1925, 21: 533-6. Remarkably, arsenic compounds were used with the intention of improving the patient's condition. Those who conceived of cancer as a constitutional or systemic disease believed that surgery and radiotherapy were not aimed at the real cause of cancer; after all, cancer's etiological agent had not been found. Therefore, these interventions were not cancer cures, they only prolonged life. See Hansemann, op. cit., note 18 above; and Otto Strauß, 'Das

Krebsheilungsproblem', Zeitschrift für Krebsforschung', 1923, 19: 185-206. 


\section{Radiotherapy in Pre-Second World War Germany}

Table 1

Radiotherapeutic treatment at the Berlin Institut für Krebsforschung from 1922 to 1927

I. Malignant tumours:

$\begin{array}{lr}\text { skin } & 159 \\ \text { larynx } & 82 \\ \text { lungs and bronchi } & 34 \\ \text { oesophagus } & 152 \\ \text { rectum } & 131 \\ \text { stomach } & 68 \\ \text { bones and joints } & 53 \\ \text { mouth and pharynx } & 183 \\ \text { cervix } & 258 \\ \text { breasts } & 708 \\ \text { other locations } & 686 \\ & 1,353 \\ & 3,867\end{array}$

of relief. This, however, was to bring Blumenthal and the IfK into conflict with those who used the scalpel as the main weapon against cancer.

That the IfK applied radiotherapy to a substantial number of patients with malignant and benign tumours is apparent from the numbers listed in Table 1, covering treatment during the six years from 1922 until $1927 .{ }^{52}$ In spite of Blumenthal's reassurance that there would be no competition between his Institute and those clinics where cancer patients were traditionally taken care of, the above data show that such a tension was almost inevitable. Furthermore, Blumenthal had a critical attitude towards operating on a cancer patient. Relapses after operations were commonly explained on the basis that surgery had apparently been performed at too late a stage or that not all the cancer cells had been removed. Blumenthal, however, held the opinion that the body was able to destroy metastasized cancer cells through its immune system. But a major operation would exhaust the body and shift the balance of the struggle towards the cancer cell: ${ }^{53}$

It often seemed as if the operation actually provoked a generalization of the disease. This could be explained by assuming that even before the operation, biologically latent cancer cells

\footnotetext{
${ }^{52}$ Ludwig Halberstädter, 'Die

Bestrahlungsabteilung des Instituts für

Krebsforschung', in Blumenthal, et al., op. cit., note 49 above, pp. 28-36.

${ }^{53}$ 'Denkschrift über die wissenschaftliche Tätigkeit des Universitätsinstituts für Krebsforschung an der Charité in den Jahren 1917-1920', 1 April 1920; HUA Char.-Dir. nr. $951,56-65$, p. 59a. Recent studies indicate that there may indeed be a mechanism that triggers
}

\begin{abstract}
latent tumour cells in the body after surgery. Presumably, this is not so much related to an impairment of the body, as to the fact that a tumour secretes one or more substances which suppress stroma formation elsewhere in the body. Such processes are now being studied under the concept of angiogenesis; see, for instance, Roy Bicknell, Claire E Lewis, and Napoleone Ferrara (eds), Tumour angiogenesis, Oxford University Press, 1997.
\end{abstract}




\section{Ton van Helvoort}

are distributed throughout the body, which are then stimulated to grow as the organism is weakened by the operation.

Obviously, the numbers in Table 1 leave unanswered the question of the therapeutic effect of radiotherapy at the IfK, and how this compared with the efficacy of surgery. As Ilana Löwy has shown, stringent clinical trials are a relatively recent phenomenon. Unsurprisingly, most pre-Second World War studies did not report comparative results. ${ }^{54}$

During the first decades of the twentieth century, surgery had a poor reputation and a diagnosis of cancer was perceived as a death sentence. One critic of surgery stated in the early 1930s: "Instead of telling us tales of the Arabian Nights, the surgeons and gynaecologists should tell us frankly how many patients treated by them were still alive 5, 10, 15 years afterwards." 55 In 1933 the Würzburg surgeon Fritz König carried out a survey in which 60 hospitals were approached and 33 responded. Three thousand patients were reported to be free of tumours after five years, most of whom had been operated upon, while only a few had received no treatment apart from radiotherapy. König concluded that "even the most obdurate pessimist cannot doubt the effectiveness of surgery in cancer control". 56

The Festschrift of the Institut für Krebsforschung on its twenty-fifth anniversary did not contain figures about the efficacy of radiotherapeutic treatment. There are obvious reasons for this. First, radiotherapy was still in its developmental stage, so the technique was changing rapidly over time. Second, in 1939 the radiotherapist Otto Jüngling from Kiel had analysed why comparative studies were so difficult to perform: the therapists had to work along strict rules of statistics; furthermore, the patients undergoing different treatments had to be in a similar clinical stage. According to Jüngling, only centralized cancer institutes could satisfy such requirements: "Such exemplary reports are available from large centres in Stockholm, Paris and Zürich and from American authors". 57

The question about the best treatment modality for cancer-surgery or radiotherapy?-led to tensions between those who operated rays and those who used the scalpel. This was the case in Germany as well as in other countries. However, the fact that X-ray and radium techniques were developed into expensive instruments, and that X-rays and radioactive substances were dangerous, stimulated the centralization of radiotherapy in large treatment centres, as well as the establishment of organizations for the administration of the radium supplies, the training of staff to handle X-rays and radioactive substances and the introduction of new legislation. The virtual non-existence of cancer charities and the strong opposition to the centralization by medical specialists meant that radiotherapy took a different course in Germany to that in many other countries.

\footnotetext{
${ }^{54}$ Ilana Löwy, 'The culture of clinical experimentation in oncology', in idem, op. cit., note 2 above, pp. 36-83.

${ }^{55}$ Cited in Fritz König, 'Die Chirurgie und Krebsbekämpfung', Archiv für klinische Chirurgie, 1939, 196: 260-7, p. 263.
}

\footnotetext{
${ }^{56}$ Ibid., p. 264.

${ }^{57}$ Otto Jüngling, Allgemeine Strahlentherapie: Licht, Röntgenstrahlen, Radium, Stuttgart, Ferdinand Enke, 1938, pp. 236-9, quotation on p. 236.
} 


\section{Radiotherapy in Pre-Second World War Germany}

\section{Philanthropy and Radium Therapy outside Germany}

This section presents a brief overview of the development of radium therapy in France, Sweden, the United States and Great Britain. ${ }^{58}$ In these countries, the high cost of radium played a crucial role in its control and in the centralization of radiotherapy.

In France, the Laboratoire Biologique du Radium (Biological Radium Laboratory) was established in 1906 under the auspices of Armet de Lisle, director of a radium factory, and in 1912 the Radium Institute came into being. One year later the University of Paris and the Pasteur Institute established a joint project on research into radiotherapy, giving three main reasons: (i) to link animal experiments with clinical research; (ii) to ameliorate the collaboration between surgeons and radiologists; (iii) because the new equipment was so costly that only co-operation could justify the large expense. ${ }^{59}$ The research into radium and its application was strongly stimulated when in 1921 Marie Curie received from the American Women's Movement a gift of 1 gram of radium. Furthermore, she was lent several grams of radium by the parent company of the Belgian Mines du Haut-Katanga (Upper Congo Mines). At Villejuif, a southern suburb of Paris, Gustave Roussy established a new cancer centre in 1920, which initially was small but soon saw major expansion. In the 1920s, a department of telecurietherapy (Fernbestrahlung, Tieftherapie, deep therapy) had been established here, headed by Simone Laborde, in which use was made of a "radium bomb" containing 10 grams. In the late $1920 \mathrm{~s}$, only six of these instruments, containing such a massive amount of radium, were operational and two of them were located in Paris, one in Villejuif and the other at the Radium Institute. ${ }^{60}$

In Sweden, Tor Stenbeck and Tage Sjögren were the founding fathers of radiotherapy. They started with self-made X-ray machines, which were used for diagnostics as well as for therapy. One of Stenbeck's pupils, Gösta Forssell, was to become the Nestor of Swedish radiotherapy. He worked at the Serafimer Hospital, the university hospital in Stockholm, whose X-ray department moved to a separate house nearby in 1910. This was named Radiohemmet (Radio Home). Subsequently, both the city of Stockholm and the state of Sweden became involved in radiotherapy. In $1916 \mathrm{a}$ new building was opened, with 34 beds for patients.

For the history of radiotherapy in Sweden, 1928 was a crucial year. On the occasion of the seventieth birthday of King Gustav V, the Swedish people offered him a present of 6 million crowns. This gift was passed on to the Swedish organization

\footnotetext{
${ }^{58}$ See also Jacques Bandaline, La lutte internationale contre le cancer-Première partie: la conception cancérologique à travers les siècles et la lutte contre le cancer en France-Deuxième partie: organisation de la lutte contre le cancer dans les divers pays, Paris, Maloine, 1933; and Cantor, op. cit., note 1 above, pp. 547-52.

${ }^{59}$ Patrice Pinell, 'Naissance et développement de la radiothérapie en France', Médecine Sciences, 1995, 11: 1596-9; see also Patrice Pinell, Naissance d'un fléau. Histoire de la lutte contre le cancer en France (1890-1940), Paris, Editions
}

\author{
Métailié, 1992, and Bénédicte Vincent, 'Genesis of \\ the Pavillion Pasteur of the Institut du Radium \\ of Paris', Hist. Tech., 1997, 13: 293-305. \\ ${ }^{60}$ In 1934 the cancer centre at Villejuif became \\ the French National Cancer Institute, known as \\ the Institut Gustave Roussy from 1948 onwards. \\ For a history of radiotherapy in France, see \\ Maurice Tubiana, Jean Dutreix, and Bernard \\ Pierquin, 'One century of radiotherapy in France, \\ 1896-1996', Int. J. Radiat. Oncol., Biol., Phys., \\ 1996, 35: 227-42.
}




\section{Ton van Helvoort}

for cancer control and was used, among other things, to establish centralized cancer treatment institutions. ${ }^{61}$ Gösta Forssell became an important spokesman for those who defended the centralization of cancer control as the most effective way of organizing it.

In the United States, the availability of radium had improved after the mid-1910s, when the US Bureau of Mines and the American Institute of Radium-founded by Howard Kelley, a gynaecologist from Baltimore, and the engineer James Douglas - set up a radium production plant in Denver. Until 1922, when uranium ores were discovered in the Belgian Congo, the main part of all the radium in the world was to be found in the United States. James Douglas donated his share of the company-in the form of several grams of radium - to the Memorial Hospital for the Treatment of Cancer and Allied Diseases in New York. ${ }^{62}$ Headed by the surgeon Henry $\mathrm{H}$ Janeway and the physicist Gioacchino Failla, the Memorial became a centre of expertise for radium therapy. ${ }^{63}$ Besides the Memorial at New York, the Collis P Huntington Memorial Cancer Hospital in Boston was also an important centre.

In England, N S Finzi, the author of the first 1913 textbook on radium therapy, brought together $600 \mathrm{mg}$ of radium for the treatment of a millionaire suffering from cancer of the bladder in 1911. During the First World War, radium was used in aeroplanes, for dials and indicators, and at the close of the war the Royal Air Force had a surplus of 5 grams, which was donated to the Medical Research Council. The MRC loaned the entire 5 grams to the Middlesex Hospital in London, predominantly for the treatment of cancer but also for experimental work. However, within two years the radium was split and divided among several clinical institutions. In 1929 the British National Radium Commission was formed to control the distribution of radium among other things to a dozen regional cancer treatment centres. ${ }^{64}$

From this brief outline of developments in four countries, we can conclude that in the second half of the 1920s important cancer hospitals and cancer research institutions were set up in each of them. The role of philanthropy in the development of cancer control in all these countries is most remarkable. The precious nature of radium and its scarcity were important factors in the centralization of radium therapy at various levels. In centralized cancer institutes, surgeons and radiotherapists were more or less forced to co-operate. A chronicler of radiotherapy in Sweden stated that because of the existence of consultative structures in that country "there has

\footnotetext{
${ }^{61}$ Later, central cancer clinics were established at Stockholm (1937), Lund (1941) and Gothenburg (1943). These were named King Gustav V Jubilee Clinics. For a history of radiotherapy in Sweden, see Elis Berven, 'The development and organization of therapeutic radiology in Sweden', Radiology, 1962, 79: 829-41.

${ }^{62}$ For a history of radiotherapy in the United States, see Juan A Del Regato, 'The unfolding of American radiotherapy', Int. J. Radiat. Oncol., Biol., Phys., 1996, 35: 5-14.

${ }^{63}$ See, for instance, Gioacchino Failla, 'Radium technique at the Memorial Hospital, New York', Radium, Nov. 1920, 16: 17-32.
}

\footnotetext{
${ }^{64}$ For a history of radiotherapy in England, see J Michael Henk, 'A brief history of British radiotherapy', Int. J. Radiat. Oncol., Biol., Phys., 1996, 36: 213-18. For a discussion of the control and regulation of radium for the purpose of experimental and clinical research before the Second World War, see David Cantor, 'The MRC's support for experimental radiology during the inter-war years', in J Austoker, and L Bryder (eds), Historical perspectives on the role of the $M R C$, Oxford University Press, 1989, pp. 181-204; see also Joan Austoker, $A$ history of the Imperial Cancer Research Fund 1902-1986, Oxford University Press, 1988.
} 


\section{Radiotherapy in Pre-Second World War Germany}

never been any kind of a fight for the patient material between the different medical branches". ${ }^{65}$ Although such statements of friendly co-operation have to be viewed with a certain scepticism, it will become clear below that in Germany radiotherapy matured in a wholly different atmosphere.

\section{Blumenthal and the Centralization of German Radiotherapy, 1928-1933}

In 1928, the Institut für Krebsforschung celebrated its twenty-fifth anniversary. In that year, Ferdinand Blumenthal was appointed extraordinary professor and from then on the IfK was financed by the state (etatmässig). Both the Institute and Blumenthal himself were internationally recognized as prominent players in cancer research and treatment, as demonstrated by the fact that he was one of two German participants at the Cancer Control conference in September $1926 .{ }^{66}$ Several employees of the Institute, such as the radiotherapist Ludwig Halberstaedter and the haematologist Hans Hirschfeld, were among the most respected experts in their specialisms. ${ }^{67}$

The developments abroad outlined in the previous section highlighted the sore point of radium shortage in Germany. In the press this became known as the "radium problem". In order to delineate a policy regarding the future of radiotherapy in Germany, a commission of the Deutsche Zentralkomite zur Erforschung und Bekämpfung der Krebskrankheit (DZK, German Central Committee on Cancer Research and Control) visited some of the radiotherapy facilities in France and Sweden. The members of the committee were Ludwig Halberstaedter of the IfK, two of the founders of the journal Strahlentherapie-Richard Werner (Heidelberg) and Hans Meyer (then in Bremen)-and Walter Friedrich of the Institut für Strahlenforschung (Institute for Radiation Research) of Berlin University. ${ }^{68}$ The conclusions of this committee, set out in a report 'Bericht der Radiumkommission über ihre Reise nach Paris und Stockholm' (Report of the Radium Committee on its Visit to Paris and Stockholm) were for the greater part adopted by the DZK, resulting in the following targets being set for the control of cancer in Germany: ${ }^{69}$

\footnotetext{
${ }^{65}$ Berven, op. cit., note 61 above, p. 837.

${ }^{66}$ American Society for the Control of Cancer, op. cit., note 4 above.

${ }^{67}$ On Halberstaedter, see anon.,

'Halberstaedter, Ludwig', in H A Strauss and W Röder (eds), Biographisches Handbuch der deutschsprachigen Emigration nach 1933-Band II, Munich, K G Saur, 1980, p. 452; on Hirschfeld, see Peter Voswinckel, 'Von der ersten hämatologischen Fachgesellschaft zum Exodus der Hämatologie aus Berlin', in W Fischer, $\mathbf{K}$ Hierholzer, M Hubenstorf, P Th Walther, and R Winau (eds), Exodus von Wissenschaften aus Berlin: Fragestellungen-Ergebnisse-DesiderateEntwicklungen vor und nach 1933, Berlin, Walter de Gruyter, 1994, pp. 552-67.

${ }^{68}$ In 1914, the medical physicist Walter Friedrich went to Freiburg im Breisgau to cooperate with gynaecologist Bernhard Krönig (see
}

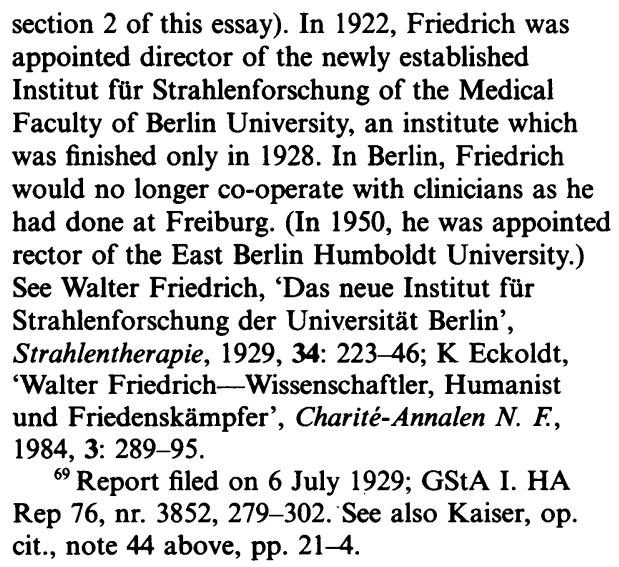
would no longer co-operate with clinicians as he had done at Freiburg. (In 1950, he was appointed rector of the East Berlin Humboldt University.) See Walter Friedrich, 'Das neue Institut für Strahlenforschung der Universität Berlin', Strahlentherapie, 1929, 34: 223-46; K Eckoldt, 'Walter Friedrich-Wissenschaftler, Humanist und Friedenskämpfer', Charité-Annalen N. F., 1984, 3: 289-95.

${ }^{69}$ Report filed on 6 July 1929; GStA I. HA Rep 76, nr. 3852, 279-302. See also Kaiser, op. cit., note 44 above, pp. $21-4$. 


\section{Ton van Helvoort}

- urging cancer patients to visit a doctor as soon as possible;

-further development and intensification of existing cancer research institutes;

- the creation of centralized institutes, possibly linked to the cancer institutes at Berlin and Heidelberg so that telecurietherapy could be effected (in all about 6 grams of radium were thought to be needed);

- establishment of smaller offices for cancer consultation and treatment with other forms of radiotherapy;

- centralization of radium and mesothorium supplies, and organization of a rational distribution of the capacity in radiotherapy;

-regulating the handling and use of radioactive substances such as radium and mesothorium, so that only trained personnel and therapists would be allowed to work with them. ${ }^{70}$

Similar themes were discussed on 31 May 1930 at a hearing organized by the Landesgesundheitsrat (County Public Health Board) on the future of cancer control. The debate was opened by contributions from Ernst Pütter (administrative director of the Charité) and Ferdinand Blumenthal. ${ }^{71}$ The latter pleaded for a centralized organization of radiotherapy to make sure that education, training and quality control could be dealt with effectively. Blumenthal concluded that radiotherapy had been introduced too rapidly, so that there was insufficient supervision of a risky, not to say potentially dangerous, technique. He argued that everyone had access to capable surgeons but that things were different for radiotherapy in general, and radium therapy in particular: "It would be a gross underestimation of X-ray and radium treatment to believe that it would suffice to put enough radium into the hands of an otherwise competent physician to achieve satisfactory radiotherapy." 72

Subsequently, the purchase of and control over radium and mesothorium were discussed and Blumenthal argued that this necessitated central institutions. Fernbestrahlungen or deep therapy (as opposed to direct application, also known as "brachytherapy") was not required so frequently that facilities had to be available everywhere. Blumenthal's conclusion was that the developments abroad should be taken as an example: "We should therefore proceed along the same lines as Sweden and France, i.e., concentrating the equipment for high-dosage telecurietherapy in a few places, while most cases are treated with smaller doses in those same or other places."73

Moreover, Blumenthal argued for the establishment of a Prüfungskommission (assessment committee), which would monitor the expertise of those working in

\footnotetext{
${ }^{70}$ In 1931, Walter Friedrich stated that for Germany the most relevant solution for the "radium problem" would be to follow the example of Great Britain, where a "middle course had been adopted between centralization and decentralization". In London, two dozen hospitals had been provided with smaller or medium amounts of radium, while four "Central Cancer Institutions" had been supplied with 1-2 grams of radium; one of these had a radium bomb containing 4 grams of radium for telecurietherapy. Over the whole of Britain, a dozen treatment centres held medium amounts of radium. See Walter Friedrich, 'Die Beschaffung
}

und Verteilung radioaktiver Substanzen für die Krebsbekämpfung in Deutschland und im Ausland', in F Grüneisen (ed.), Krebsbekämpfung:

Jahrbuch des Reichsausschusses für

Krebsbekämpfung 1930, Leipzig, Johann

Ambrosius Barth, 1931, pp. 86-90, p. 87.

${ }^{71}$ Ernst Pütter, Ferdinand Blumenthal, et al., 'Organisation der Krebsfürsorge [Bericht über die Sitzung eines zusammengesetzten Ausschusses des Landesgesundheitsrats am 31. Mai 1930]',

Veröffentlichungen aus dem Gebiete der

Medizinalverwaltung, 1930, 32: 635-94.

${ }^{72}$ Ibid., p. 651 .

${ }^{73}$ Ibid., p. 652. 


\section{Radiotherapy in Pre-Second World War Germany}

radiotherapy. This would result in better protection of patients as well as doctors and therapists against the harmful effects of radioactive rays. All this had to be laid down in legislation.

The work of the radium committee of the DZK testifies to the importance radiotherapy had gained in the treatment of cancer. Not only were the pros and cons of introducing regulation of radiotherapy discussed but also who would have jurisdiction over the technique. Walter Stoeckel, head of the Universitäts-Frauenklinik (University Gynaecological Clinic) of the Charité, warned against the consequences of centralizing radiotherapy: "Founding centralized cancer institutes would provoke further opposition from all sides, including specialists and specialized institutes. It would arouse the not unreasonable fear that a major part of their own work might be taken away from them." ${ }^{74} \mathrm{He}$ was referring to the surgeons, gynaecologists, dermatologists, oto-laryngologists and to a lesser extent orthopaedists. These specialists claimed that cancer as a disease of a specific organ had to be treated by those who were experts in that particular medical domain. Thus, cancer of the cervix fell under the jurisdiction of gynaecologists. According to Stoeckel, this situation was the result of a historical process which should not be interfered with by creating a new specialism encompassing different fields of expertise. Stoeckel clearly opposed the centralization of radiotherapy striven for by Blumenthal, but the latter secured support from, for instance, the Cologne radiologist Werner Teschendorf, who openly advocated the establishment of special clinics for radiotherapy. Teschendorf claimed that much "cancer therapy" was being lost through injudicious use. ${ }^{75}$

In 1931 Blumenthal and Teschendorf came under severe attack from the Medical Faculty of the University of Frankfurt am Main, an attack articulated by its dean, A Loos. ${ }^{76}$ The immediate cause which brought the different points of view into the open was the formation of the Reichsausschuß für Krebsbekämpfung. Its inauguration on 25 February 1931 was a most important step, because it marked the beginning of government participation in cancer control. And, interestingly, the committee's chairman Bruno Dammann and secretary Félix Grüneisen seemed to opt for the centralization of radiotherapy as Blumenthal had advocated. ${ }^{77}$

Loos accused Blumenthal of attempts to withdraw the treatment of cancer patients from the disciplines that claimed jurisdiction over diseased organs and to establish centralized cancer hospitals and institutes. This, he claimed, would be harmful for the training of doctors and specialists. Loos referred to an article written by Frankfurt's Hans Holfelder, which defended local integration of radiotherapy with

\footnotetext{
${ }^{74}$ Walter Stoeckel, contribution to the discussion in Pütter, et al., op. cit., note 71 above, p. 680 .

${ }^{75}$ Werner Teschendorf, 'Zentralisation der Geschwulstbehandlung', Zeitschrift für Gesundheitsverwaltung und Gesundheitsfürsorge, 1931, 2 (2): 33-42, p. 36.

${ }^{76}$ A Loos, 'Über die zweckmässigste Organisation der Krebsbekämpfung', Dtsch. med. Wochenschr., 1931, 57: 1487-9. Apparently, Werner Teschendorf was spared further criticism.
}

See, for instance, Goerke, op. cit., note 5 above, p. 100, and Teschendorf's contribution 'Zur Krebsbekämpfung', in C Adam and H Auler (eds), Neuere Ergebnisse auf dem Gebiete der. Krebskrankheiten: 47 Vorträge, Leipzig, S Hirzel, 1937, pp. 208-16.

${ }^{77}$ See, for instance, Félix Grüneisen, 'Ein Jahr Reichsausschuß für Krebsbekämpfung-1. April 1930-31. März 1931', in Grüneisen (ed.), op. cit., note 70 above, pp. 10-21. 


\section{Ton van Helvoort}

the surgical specialisms. ${ }^{78}$ Holfelder's institute was, on the one hand, a centralized establishment with large spaces for the megavolt X-ray devices, while on the other it was integrated with the university's surgical clinic headed by Victor Schmieden. Holfelder stated that the X-ray department performed no surgery of whatever kind, as this was the proper domain of the Surgical Clinic. ${ }^{79}$

Criticism of Blumenthal became even sharper when Germany's most prominent surgeons, Hans Küttner (Breslau), Ferdinand Sauerbruch (Charité, Berlin) and Victor Schmieden (Frankfurt am Main), openly joined in the conflict, claiming that surgeons were deliberately being excluded from the Reichsausschuß. ${ }^{80}$ If Blumenthal was critical about the legitimacy of cancer surgery in many cases, surgeons were most critical about the results claimed by the radiotherapists. They referred to patients who "would develop into hopeless cases as a result of useless radiotherapy and so be lost to cure". In their view, the radiotherapist was only to be called in after the surgeon had given permission: "Generally speaking, the radiotherapist should be called in only after the possibilities for surgical treatment have been exhausted or have been rejected on good grounds."

In July 1932, the medical faculty of Berlin University decided to cut the budget of Blumenthal's Institut für Krebsforschung by 20,000 Marks, of which one-fifth affected Rhoda Erdmann's Institut für experimentelle Zellforschung (Institute for Experimental Cell Research). Although the latter was independent, it still was financially tied to the IfK. Blumenthal wrote to Charite's administrative director Alfred Kuhnert saying that a budget cut of this magnitude would in fact imply the end of the IfK as a research institute. In Blumenthal's view, the attack on his Institute was inspired by the competition between the IfK and the regular clinics and institutes where radiotherapeutic devices for the treatment of cancer patients were also available. The argument of his adversaries, Blumenthal claimed, was that "radiative treatment of cancer could just as well be performed and developed at the surgical clinics" ${ }^{82} \mathrm{He}$ concluded that "the independence of cancer research and cancer treatment in Germany [appeared to be] under attack from two different directions-pathology and surgery" ${ }^{83}$

As mentioned above, Blumenthal devoted his experimental cancer research to a wide range of models. The conclusions drawn from these studies for the etiology of human cancer were unacceptable to many clinicians and orthodox pathologists. To

\footnotetext{
${ }^{78}$ Hans Holfelder, 'Gedanken zur örtlichen Organisation der Krebsbekämpfung', Dtsch. med. Wochenschr., 1931, 57: 659-62.

${ }^{79}$ Hans Holfelder and Walter Körte, Das Röntgeninstitut der chirurgischen Universitätsklinik im Städtischen Krankenhaus Sachsenhausen in Frankfurt a. M., Leipzig, Georg Thieme, 1929, p. 25.

${ }^{80}$ Hans Küttner, Ferdinand Sauerbruch, and Victor Schmieden, 'Die Chirurgie des Krebses und die neuen organisatorischen Bestrebungen zur Krebsbekämpfung', Med. Welt, 1931, 5: 981-5. In response to this, the chairman of the Reichsausschuß, Bruno Dammann, quickly
}

involved the surgeons in the committee's further activities. See Bruno Dammann, 'Die Ziele des Reichsausschusses für Krebsbekämpfung', ibid., 1931, 5: 986; for his earlier position, see Bruno Dammann, 'Wege und Ziele der Krebs-

bekämpfung', in Grüneisen (ed.), op. cit., note 70 above, pp. 1-9. See also Kaiser, op. cit., note 44 above, pp. 22-30.

${ }^{81}$ Küttner, et al., op. cit., note 80 above, pp. 984-5.

${ }^{82}$ Blumenthal to Alfred Kuhnert, 25 July 1932; HUA Char. Dir. nr. 953, 246-53, p. 248.

${ }^{83}$ Ibid., p. 248. 


\section{Radiotherapy in Pre-Second World War Germany}

give an example, the surgeon Victor Schmieden, co-author of the 1931 attack on Blumenthal, had written a few years before:

It is alien to the clinician's mode of thinking not to rely on conclusive evidence from human materials, but time and again to be referred to mammals, thence to birds, thence to coldblooded animals and even to plants (sunflowers etc.)... [W] must warn against attaching too much value to comparative observations from the animal or plant kingdom. ${ }^{84}$

This comment was written in response to the publicity that the research on cancer viruses had received in the mid-1920s. ${ }^{85}$ And in 1937 Ferdinand Sauerbruch, co-author of an anti-Blumenthal article, formulated his hesitation about animal experiments as follows: "Clinicians will be particularly apprehensive about simply transferring the results of animal experiments to human pathology and about generalizing and overestimating the extent of their significance." 86 Therefore, when Blumenthal wrote that independent cancer work was being attacked by pathology and surgery he had in mind both his research programme and the radiotherapeutic treatment of cancer patients.

The warm relationship between the chairman and the secretary of the Reichsausschuß on the one hand and Ferdinand Blumenthal on the other had flagged and the committee now established firm ties with the Deutsche Gesellschaft für Gynäkologie (German Gynaecological Society) as well as the Deutsche Gesellschaft für Chirurgie (German Surgical Society). Subsequently, surgeons, gynaecologists and other specialists succeeded in averting the centralization of radiotherapy in Germany.

Blumenthal's Institut für Krebsforschung received the final blow with the introduction on 7 April 1933 of the Gesetz zur Wiederherstellung des Berufsbeamtentums (Civil Law of 7 April 1933) which banned persons of Jewish descent from entering state service. ${ }^{87}$ Since Blumenthal and almost all of his staff and personnel were Jewish, he was forced to take early retirement; shortly afterwards he emigrated to Belgrade where he became professor, while Ludwig Halberstaedter and Hans Hirschfeld emigrated too. ${ }^{88}$ Hans Auler, Blumenthal's personal assistant, was made acting director of the IfK.

\footnotetext{
${ }^{84}$ Victor Schmieden, 'Infektion, Parasitismus und Gewächsbildung', in G Schmorl (ed.), Verhandlungen der Deutschen Pathologischen Gesellschaft: zweiundzwanzigste Tagung, gehalten in Danzig am 8.-10. Juni 1927, Jena, Gustav Fischer, 1927, pp. 21-36, on pp. 30, 34, respectively.

${ }^{85}$ Van Helvoort, op. cit., note 43 above; see also idem, 'Viren als Krebserreger: Peyton Rous, das "Infektiöse Prinzip" und die Krebsforschung', in C Gradmann and T Schlich (eds), Strategien der Kausalität: Konzepte der Krankheitsverursachung im 19. und 20. Jahrhundert, Pfaffenweiler, Centaurus-Verlagsgesellschaft, 1999, pp. 185-226, and idem, 'A century of research into the cause of cancer: is the new oncogene paradigm revolutionary?', Hist. Philos. Life Sci., 1999, 21: 293-330.

${ }^{86}$ Ferdinand Sauerbruch and Else Knake, 'Bericht über weitere Ergebnisse experimenteller
}

Tumorforschung', Arch. Klin. Chirur., 1937, 189: 185-90, p. 190.

${ }^{87}$ See Andreas Fijal, 'Die Rechtsgrundlagen der Entpflichtung jüdischer und politisch mißliebiger Hochschullehrer nach 1933 sowie des Umbaus im nationalsozialistischen Sinne', in Fischer, et al. (eds), op. cit., note 67 above, pp. 101-15. See also Robert N Proctor, 'The Gleichschaltung of German cancer research', in idem, The Nazi war on cancer, Princeton University Press, 1999, pp. 35-57.

${ }^{88}$ See Michael Hubenstorf and Peter Th Walther, 'Politische Bedingungen und allgemeine Veränderungen des Berliner Wissenschaftsbetriebes 1925-1950', in Fischer, et al. (eds), op. cit., note 67 above, pp. 5-100, pp. 34-5; see also anon., 'Einleitung, in Strauss and Röder (eds), op. cit., note 67 above, Band I: Politik, Wirtschaft, Öffentliches Leben, pp. I-LVIII. 


\section{Conflicting Views on the Continuation of the Institut für Krebsforschung}

After the almost complete dismantling of the IfK in April 1933, the dean of the Medical Faculty of the University of Berlin, Hermann Gocht, tried to delineate new aims for the Institute. He was the chairman of the Deutsche Orthopädische $\mathrm{Ge}-$ sellschaft (German Orthopaedic Society) and was greatly involved in the development of radiology because of the crucial role X-ray diagnostics played in his profession. ${ }^{89}$ Gocht sought advice from several experts, including the gynaecologist Walter Stoeckel (Charité), the surgeon Victor Schmieden (Frankfurt am Main) and the radiologists Gösta Forssell (Stockholm) and Hans Schinz (Zürich).

In 1930, Stoeckel had warned that attempts to centralize radiotherapy would meet with serious resistance from medical specialists. And in his advice to Gocht he was also very outspoken against a centralized radiotherapeutic institute at the Charite:

Whenever the founding of a centralized institute for radiotherapy or the establishment of a cancer hospital was discussed, the faculty has emphatically rejected the centralization of either radiotherapy or cancer treatment. It is absolutely essential that each clinic retains the right and has the necessary equipment to irradiate patients and treat cancers. This necessity derives especially from the fact that radiotherapists are insufficiently trained in either diagnostics or therapy to solve the problems that need to be solved with regard to cancer diagnostics and cancer therapy.

Although Stoeckel admitted that radiotherapy had its place in the treatment of cancer, he felt, nevertheless, that the main responsibility was with the clinician: "It is only the clinician who is capable of assessing and implementing this kind of therapy, not the radiotherapist". Stoeckel did not object to the IfK as a research institute, as long as it did not have therapy as its main objective.90

The Frankfurt surgeon Victor Schmieden, who with Küttner and Sauerbruch had criticized Blumenthal openly, was asked for advice too. His view was typical of a surgeon: (i) the cancer patient had to be treated by the specialist with competence over the organ or organs affected; (ii) surgery had to be the first line of treatment; (iii) cancer treatment should never be based on a one-sided radiotherapeutic approach. Schmieden had always been offended by the IfK's pretending to be a therapeutic institute: ${ }^{91}$

I have also always resented the presence in the Luisenstrasse in Berlin of an institute which openly advertises itself to the public at large as a therapeutic institute for tumour diseases.... The real tumour diseases, especially cancer, however, are so intimately linked to the various clinical disciplines that it would be impossible to tear these types of disease away from internal medicine, surgery, gynaecology, laryngology, etc. and place their diagnosis and treatment under the responsibility of a special therapist who looks only at this aspect.

\footnotetext{
${ }^{89}$ Gocht's own position with respect to the IfK did not become clear. Gocht was editor of the literature review Die Röntgen-LiteraturZugleich Anhang zu'Gochts Handbuch der Röntgen-Lehre', Stuttgart, Enke, 1911ff. On Hermann Gocht, see Holthusen, et al. (eds), op. cit., note 25 above, pp. 30-2; Goerke, op. cit., note 5 above, pp. 19-20; and Uwehorst Paul
}

(ed.), 150 Jahre Berliner Orthopädie, Berlin, Humboldt-Universität, 1985, pp. 70-7.

${ }^{90}$ Walter Stoeckel to Hermann Gocht, no date; HUA Med. Fak. 279, Bd 1, 100.

${ }_{91}$ Victor Schmieden to Hermann Gocht, 6 June 1933; HUA Med. Fak. 279, Bd 1, 27-30, pp. 27-8. 


\section{Radiotherapy in Pre-Second World War Germany}

Schmieden held the opinion that since surgery was in the vanguard of cancer treatment, the cancer patient should seek refuge in a combination of surgical and radiotherapeutic interventions "but not in a purely surgical, nor in a purely radiological therapy". 92

Stoeckel and Schmieden represented the established disciplines, but radiologists were consulted too. Gösta Forssell, head of the Sophiahemmets Röntgeninstitut at Stockholm, persevered in pleading for the centralization of radiotherapy. He advised performing radiotherapy in an independent clinic with an outpatient department, although in "carefully organized collaboration" with the other clinics where surgery was practised. He advised Gocht to transfer the experimental research to the Charité's Pathological Institute. ${ }^{93}$

The second radiotherapist consulted was Hans $\mathrm{R}$ Schinz, professor of medical radiology at Zürich and chairman of the Fourth International Congress of Radiology, held in Zürich in 1934. In his advice to Gocht, Schinz clearly expressed sympathetic feelings towards National Socialism, so a pro-Blumenthal position was hardly to be expected from him. He stated that now that the National Socialist revolution in Germany had succeeded, the country could catch up with such countries as Sweden with its Radiohemmet, the United States with its Memorial Hospital, Milan with its Instituto del Cancro and Paris with its Institut du Radium. Schinz concluded that cancer surgery in Germany was well organized, unlike treatment by radiotherapy. He held the view that centralization would be inevitable: "All leading radiotherapists support the centralization of radiotherapy." In the Romance, Anglo-American and Scandinavian countries, centralized cancer institutes had been founded, as it was impossible for a radiotherapist to work efficiently "in an institute which functions only as a nursing home for incurable cancer patients". With regard to the situation in Germany, his judgement was most critical: "The decentralization undertaken in most places in Germany has yielded disappointing results, and despite our great sympathy for Germany it must be said that, except as regards gynaecological radiotherapy, this has caused Germany, which has always marched at the forefront of science, to lag behind." Schinz was familiar with the Berlin Institut für Krebsforschung and believed that the "existing cancer institute should not only be continued but should be expanded into a radiotherapeutic cancer centre, which should primarily be led by a radiotherapist". In such an institute there was no need for extensive operations, as surgery and radiotherapy were independent disciplines: "A clear separation between these two treatment modalities should and can be made."94

Schinz's views on the Berlin IfK were very similar to the objectives set out by Blumenthal. The consultations by Gocht resulted in the same division along party lines as had existed while Blumenthal was director of the Institute. Radiotherapists strove for centralization of treatment facilities, while the medical specialists defended their jurisdiction over the use of radiotherapy.

${ }^{92}$ Ibid., pp. 29-30.

${ }^{93}$ Gösta Forssell to Hermann Gocht, 7 June 1933; HUA Med. Fak. 279, Bd 1, 31-8, p. 34.

\footnotetext{
${ }^{94}$ Hans R Schinz to Hermann Gocht, 7 June 1933; HUA Med. Fak. 279, Bd 1, 40-7, pp. 41-2, pp. $44-5$, respectively.
} 


\section{Ton van Helvoort}

\section{The Conflict over Centralization Continues}

The disagreement between radiotherapists and clinicians was also apparent during the 1934 Fourth International Congress of Radiology, chaired by Hans Schinz (in which Blumenthal did not participate). Keynote lectures were given by Gösta Forssell and Ferdinand Sauerbruch and the theme was the organization of radiotherapy.

With regard to specialization and co-operation, Forssell took the following position: "It is no longer a matter of whether cancer treatment should be centralized, but of the extent to which and the principles on which this is to be implemented". ${ }^{95}$ In the case of treatment with radium, Forssell held that this should be performed in central clinics for radiotherapy. Sauerbruch, who represented clinical medicine, understood the tension between surgery and radiotherapy. He saw it as inevitable "that there was initially a certain rivalry between the two sister disciplines, notwithstanding their great similarity in many fundamental respects. Roentgenology tried to contest the authority of the older surgical discipline, while the latter often out of prejudice denied or underestimated the prospects of radiology and hence rejected it". And with reference to Forssell's keynote address, Sauerbruch expressed his gratitude for the "guidelines provided by his ground-breaking work, though certain details will have to be adapted to the circumstances". ${ }^{96}$ But the crucial issue was of course which "details" would have to be adapted in order to meet the German situation.

The way Sauerbruch formulated the problem, it seemed as if the question was over which of the two techniques - the use of the scalpel or radiotherapy-was most beneficial to the cancer patient. But, as will have become clear from this account, it was not so much a dispute over what constituted the best technique but under whose jurisdiction radiotherapy fell.

In view of the contradictory recommendations Hermann Gocht received regarding the continuation of the Institut für Krebsforschung, it is not surprising that no firm decision was reached. Temporarily, Sauerbruch was appointed curator, while Hans Auler was in charge of the day-to-day running of the Institute. Under Sauerbruch, experimental cancer research entered new avenues. The experimental models studied by Blumenthal were almost all abandoned. Sauerbruch believed that the course of a disease was determined by the body as a whole. This constitutional or pathophysiological notion of disease had become fashionable since the 1920s and had resulted in dietary studies and hormone research. Thus Sauerbruch and his coworkers had developed a dietary treatment for tuberculosis.$^{97}$ In cancer, disturbances

\footnotetext{
${ }^{95}$ Gösta Forssell, 'Organisation der Krebsbekämpfung', in H E Walther (ed.), IV. Internationaler Radiologenkongress Zürich 1934, Leipzig, Kommissionsverlag Georg Thieme, 1935, pp. $56-63$, p. 61 .

${ }^{96}$ Ferdinand Sauerbruch, 'Verhältnis der Chirurgie zur Radiologie', in ibid., pp. 63-8, pp. 65-6.

${ }^{97}$ Ferdinand Sauerbruch, et al., 'Die

Bedeutung der von Sauerbruch, Hermannsdorfer und Gerson angegebenen Diät bei der Behandlung der Tuberkulose-Bericht über die
}

\begin{abstract}
Sitzung eines zusammengesetzten Ausschusses des Landesgesundheitsrats am 28. Februar 1930', Veröffentlichungen aus dem Gebiete der Medizinalverwaltung, 1930, 32: 543-632; on research into constitutional aspects of disease in Germany see, for instance, Gerhard Koch, Die Gesellschaft für Konstitutionsforschung: Anfang und Ende 1942-1965, Erlangen, Palm und Enke, 1985, and also Proctor, 'The Nazi diet', in idem, The Nazi war on cancer, op. cit., note 87 above, pp. 120-72. For the further development of Gerson's dietary therapy for cancer, see S J
\end{abstract}


of the hormone balance, for example as a consequence of advancing age, were assumed to play a role. In his paper 'Die Bedeutung von Sexualstörungen für die Entstehung von Geschwülsten' (The impact of sexual disorders on the genesis of tumours), Sauerbruch argued that the anatomical orientation had dominated cancer research too much, "while general pathological disorders of the organism as a whole were neglected" ${ }^{98}$ The physiological approach advocated by Sauerbruch was studied in more detail by Hans Auler, who did research on, for instance, the influence of climate on the genesis of cancer in laboratory animals. ${ }^{99}$

As stated above, the Reichsausschuß für Krebsbekämpfung was initially biased in favour of the centralization of radiotherapy, a point of view that was abandoned under pressure from the German Societies for Gynaecology and Surgery. In spite of this, the committee urged the National Socialist government to create three professorships of radiology in $1935 .{ }^{100}$ They were situated in Hamburg, Cologne and Leipzig and it will be no surprise that Berlin was not included in the list.

In the late 1930s the conflict over radiotherapy in relation to the clinical specialisms was as heated as it had been a decade before. At the last meeting of the Deutsche Röntgengesellschaft (German Roentgen Society) before the Second World War, held in May 1939 at Stuttgart, the problem was addressed again. Hans Holfelder-who in 1931 had pleaded for local radiological institutes, integrated with surgical departments-now advocated the creation of centralized institutes for roentgenology, not only for radiotherapy but for X-ray diagnosis as well. Again, the representatives of the clinical specialisms objected strongly. Alfred Schittenhelm of the Deutsche Gesellschaft für Innere Medizin (German Society for Internal Medicine) contended that "the various specialized clinics [should] be allowed to keep their own X-ray institutes". Martin Kirschner, representing the Deutsche Gesellschaft für Chirurgie, provokingly stated that roentgenologists were aiming "to establish for themselves a free territory to work in, without any competition". And Heinrich Martius of the Deutsche Gesellschaft für Gynäkologie claimed that the gynaecologist not only had to do his own X-ray diagnostics, but should also "retain control of his own radiotherapy". ${ }^{101}$

In 1939, the X-ray department of Sauerbruch's Surgical Institute merged with that of the Institut für Krebsforschung. ${ }^{102}$ Meanwhile, the clinical department of the IfK

Haught, Censured for curing cancer: the American experience of Dr. Max Gerson, Bonita, CA, The Gerson Institute, 1991. The conflict between reductionist and holistic studies of the human cancer problem is discussed in van Helvoort, op. cit., note 43 above.

${ }^{98}$ Ferdinand Sauerbruch and Else Knake, 'Die Bedeutung von Sexualstörungen für die Entstehung von Geschwülsten', $Z$.

Krebsforschung, 1936, 44: 223-39, p. 223; see, for instance, also Helmuth M Böttcher, Hormone: die Geschichte der Hormonforschung, Cologne, Kiepenheuer \& Witsch, 1963.

${ }^{99}$ Hans Auler, 'Geschäftsbericht des Deutschen Reichsausschusses für

Krebsbekämpfung', Zeitschrift für

Krebsforschung, 1940, 49: 217-20, p. 220.

\footnotetext{
${ }^{100}$ Heilmann, op. cit., note 5 above, p. 211. On the relationship between the Reichsausschuß für Krebsbekämpfung and National Socialist ideology, see Félix Grüneisen, 'Krebsbekämpfung im nationalsozialistischen Staat', Dtsch. med. Wochenschr, 1933, 59: 1498-9; Hans Auler, 'Die Aufgaben der Krebsbekämpfung im nationalsozialistischen Deutschland', Fortschr. Gesundheitsfürsorge, 1934, 8: 125-33; Max Borst, 'Begrüßungsansprache', Z. Krebsforschung, 1940, 49: 216. 78-84.

${ }^{101}$ Cited in Goerke, op. cit., note 5 above, pp.

${ }^{102}$ Dagobert Müller, 250 Jahre Charité, Berlin, VEB Graphische werkstätten, 1960, pp. 25-7.
} 


\section{Ton van Helvoort}

was deteriorating rapidly. After a complaint from a patient in 1942, the head of the Gesundheitsamt Berlin-Mitte wrote: "In any case, the nursing ward of the institute in its present state is a disgrace and should be closed down by the police."103 This meant an inglorious end to an institute that had been made internationally renowned by Ferdinand Blumenthal.

\section{Scalpel or Rays?}

The present essay has discussed how a new treatment modality for cancerradiotherapy-was introduced and how this technique had to struggle for a niche of its own. It had to compete with orthodox therapy, i.e. surgery. The development of radiotherapy in Germany, and the history of the Institut für Krebsforschung of the Berlin Charite in particular, constitutes an interesting case study because the course taken differed from that in surrounding countries. Since centralized cancer institutes had been established in France and Sweden, Ferdinand Blumenthal strove for a similar role for his Institut für Krebsforschung; however, this met with vigorous resistance from the orthodox clinical specialisms.

That the struggle between medical specialists and radiotherapists trying to establish an independent specialism of their own was so intense and protracted was related to several specific characteristics of X-ray and radium technology, which applied not only in Berlin and in Germany as a whole, but in other countries as well. First, the introduction of therapeutic X-ray devices developed from X-ray diagnostics, the latter technique being of great importance to many medical specialisms. As the X-ray tube and related appliances were relatively cheap, $X$-ray diagnostics was widely available. When, in the early twentieth century, X-ray therapy of cancer was initiated, this seemed to be a change of degree rather than of kind. Second, like X-ray therapy, radium therapy was a technique which was highly "democratic". Although radium and mesothorium were costly, in many cases some tens or hundreds of milligrams were enough to produce excitingly high rates of cure. The situation changed when in countries such as England, France, Sweden and the United States impressive results were obtained by using "radium bombs", which contained grams of radium. The radium shortage which had been a problem in Germany from the beginning of the twentieth century was then acutely felt. Or, as Blumenthal said at a cancer conference in 1930: "there is no other medical discipline ... where this lack of funds has been so noticeable-I refer to the high price of radium - and where we have therefore been lagging behind other nations so seriously in the research on and treatment of cancer."104 To sum up, radium was both a "democratic agent" and a "centralizing agent", depending on the form of therapy, i.e. brachytherapy or Fernbestrahlung (deep therapy).

Third, another argument for centralizing radiotherapy stemmed from the inherent hazards of radioactive rays, which constituted a health problem for the therapist as well as for the patient. This required several precautionary measures: (i) radiotherapists had to be educated and trained to prevent dilettantism; (ii) legislative regulations for

${ }^{103}$ Kaiser, op. cit., note 44 above, p. 73.

${ }^{104}$ Ferdinand Blumenthal, 'Krebskonferenz in
Dresden vom 11.-13. Juni 1930', $Z$.

Krebsforschung, 1930, 31: 632-6, p. 636. 


\section{Radiotherapy in Pre-Second World War Germany}

handling radioactive substances were needed; (iii) the production and handling of such radioactive substances had to be restricted to specially trained and certified staff. ${ }^{105} \mathrm{Of}$ course these requirements would greatly enhance the professionalization of the new sub-discipline of radiodiagnostics and radiotherapy. In the wake of this, professional associations and vocational training could be taken care of.

However, there were also fundamental differences between Germany and the other countries mentioned above. We have seen that the development of radiotherapy was influenced by national political as well as economic factors. Unlike the United States, Germany hardly possessed any uranium mines, nor did it have colonies where the minerals could be extracted, unlike Belgium, which imported uranium ores from the Upper Congo. A further difference between Germany and countries such as Sweden, France and the United States was that philanthropy benefiting cancer research and treatment played a much smaller part in the former than in the latter countries. Although Blumenthal's Institute was supported financially by a bank and some industries, and the Cancer Hospital (Samariterhaus) at Heidelberg depended on private donations, these were only a fraction of the contributions received elsewhere, such as James Douglas's donation of radium to the New York Memorial Hospital, that of the United States to Marie Curie, and the birthday gift of the Swedish king given to the Swedish organization for cancer control. This philanthropy was a crucial factor in the "forced" centralization of radiotherapy in those countries. ${ }^{106}$

Moreover, the German authorities long remained aloof regarding the control of cancer, an attitude which altered only when the Reichsausschuß für Krebsbekämpfung was set up. Although this committee had the centralization of radiotherapy high on its agenda, it eventually withdrew its plans when German specialists and their organizations opposed Blumenthal's scheme for the organization of radiology.

Blumenthal was a proponent of the concentration of cancer research in independent institutes because he felt that researchers at other institutes were under no obligation to work on the cancer problem: ${ }^{107}$

The difference between the Universitätsinstitut für Krebsforschung at the Charité and all of these institutes, including the above-mentioned Kaiser Wilhem Institutes [of Biology and of Biochemistry], is that these institutes could switch to other subjects tomorrow, without any problem; for them, cancer is only a part of their research task, while the cancer institute is devoted purely to cancer research.

An important aspect of the present case study is that it shows how a new medical technique and its proponents had to struggle for a niche within the network of tasks, instruments and methods of the existing forms of cancer treatment. In this situation,

${ }^{105}$ Gösta Forssell of the Swedish Radiohemmet also perceived such problems as important obstacles for the rational practice of radiotherapy: "The greatest obstacles that have so far stood in the way of cancer therapy have been the lack of professionalism in the implementation of radiotherapy and the fragmentation of its powers and its weaponry." See Forssell, 'Organisation der Krebsbekämpfung', in Walther (ed.), op. cit., note 95 above, p. 57.

\footnotetext{
${ }^{106}$ This is an example of how philanthropic and charitable organizations can influence the development of cancer control. Cf. David Cantor, 'Contracting cancer? The politics of commissioned histories', Soc. Hist. Med., 1992, 5: 131-42.

${ }^{107}$ Blumenthal to Von Eicken, 28 Feb. 1929; HUA Med. Fak. 269, 12a.
} 


\section{Ton van Helvoort}

the establishment was formed by surgeons, gynaecologists and internists, while, according to the formal hierarchy of German medicine, medical clinics and institutes were governed as if they were independent kingdoms. ${ }^{108}$ From these powerful positions, their managers tried to retain their jurisdiction over the cancer patient by claiming competence over the new instruments for radiotherapy.

Those who applied orthodox cancer therapies formulated the problem of the introduction of the new cancer intervention technique as if it were necessary to decide which therapy - surgery or radiotherapy - was the most effective for the cancer patient. Thus, to their question, "Scalpel or rays?" they replied that surgery was the prime line of attack; operation and radiotherapy could best be applied together; and those who were trained to use the scalpel also controlled the use of the new radiotherapeutic devices, or at least that these could be used only under their supervision. Although the discussion was presented as concerned with which intervention technique was most effective, what was actually at stake was the authority over the cancer patient.

Thus, the present case study illustrates how a technological innovation was apparently discussed at the technological level, while, at the same time, there was a struggle for jurisdiction over the new technique and the competence to apply it. Certain circumstances which were specific to Germany, i.e. the radium shortage, the lack of a tradition of cancer philanthropy, the power of the German medical elite at the universities and the reluctance of the German government to play a part in cancer control, meant that the development of radiotherapy took a different course from that in other European countries and the United States. ${ }^{109}$ Moreover, this contributed greatly to the fact that cancer research as an independent specialism took longer to establish itself in Germany than elsewhere. This situation was not to be reversed until the 1960 s. ${ }^{110}$

${ }^{108}$ Stoeckel, op. cit., note 13 above, p. 121.

${ }^{109} \mathrm{On}$ the role of German authorities and cancer control, see for instance, Proctor, 'The campaign against tobacco', in idem, The Nazi war on cancer, op. cit., note 87 above, pp. 173-247.

\footnotetext{
${ }^{110}$ It was not until the second half of the 1960s that Karl Heinrich Bauer succeeded in mobilizing enough support for a German National Cancer Institute. See Wagner and Mauerberger, op. cit., note 8 above.
} 